\title{
Beta-thalassemia Intermedia From Two Japanese Families
}

\author{
Jun Sasaki, M D, Takashi Imamura, M D, KiyohideNunor, M D, \\ Katsunori Shibata, M D Kotaro Yamaoka, M D, \\ and Toshiyuki Yanase, M D \\ The First Department of Medicine, Faculty of Medicine, \\ Kyushu University, Fukuoka
}

\begin{abstract}
Two cases of heterozygous $\beta$-thalassemia with unusually severe anemia and hepatosplenomegaly are described. Their $\mathrm{Hb} \mathrm{A}_{2}$ and $\mathrm{Hb} \mathrm{F}$ levels were shown to be in the range of the typical $\beta$-thalassemia trait. Bone marrow examinations showed marked erythroid hyperplasia and increased iron stores. Relative rates of $\beta$ - and $\alpha$-globin chain synthesis in the peripheral reticulocytes and bone marrow cells were within the range of the usual $\beta$-thalassemia trait. Of the total of 6 carriers in the first case, three members including the propositus exhibited more severe clinical and hematological abnormalities than three others who showed only mild anemia and red cell morphological changes seen in the usual $\beta$-thalassemia trait. In the second case, the proposita had a moderately severe anemia, while three other members of the family showed only mild hypochromic anemia, their biochemical features being those of the usual $\beta$-thalassemia trait. The findings presented here indicate that the phenotypical expression of thalassemia genes might be modified by some environmental factors and by interactions with other genetic constitutions, although these conditions are yet poorly understood.
\end{abstract}

Key Words : Hemoglobin; Globin synthesis; Hemolytic anemia.

The thalassemia syndromes are a group of genetic disorders characterized by reduced or absent synthesis of one or more of the globin chains which form the apoprotein portion of the hemoglobin molecule ${ }^{1)}$. Surveys currently being carried out in this laboratory suggest that though the incidence is obviously low there are a substantial number of patients with thalassemia among the Japanese ${ }^{2)}$. By far the most common form found in Japanese people appears to be heterozygous $\beta$-thalassemia. When data on $\beta$-thalassemia heterozygotes from popu-

Received for publication May 13, 1977.

Reprint request to: Jun Sasaki, The First Department of Internal Medicine, Faculty of Medicine, Kyushu University, 1-1, 3-chome Madashi, Higashi-ku, Fukuoka, 812, Japan. lations throughout the world are studied, a remarkably similar clinical picture is apparent, being characterized by a mild anemia and the presence of morphological changes of the red cells associated with low mean corpuscular hemoglobin (M.C.H.) and mean corpuscular volume (M.G.V.). Hepatosplenomegaly was absent in most cases. Hemoglobin $\mathrm{A}_{2}$ levels are significantly high ranging from $4 \%$ to $6 \%$ of the total hemoglobin. Such hemogeneity suggests that the $\beta$-thalassemia heterozygote with severe anemia and splenomegaly, or the findings of unusually high levels of $\mathrm{Hb} \mathrm{A}_{2}$ and $\mathrm{Hb}$ $F$ must be viewed with caution, and that such unusual cases probably represent different genetic constitutions ${ }^{1}$.

The present paper is concerned with 
Table 1. Hematologic and hemoglobin measurements in affected subjects.

\begin{tabular}{|c|c|c|c|c|c|c|c|c|c|c|}
\hline & Age, sex & $\begin{array}{c}\mathrm{Hb} \\
\mathrm{g} / 100 \mathrm{ml}\end{array}$ & $\begin{array}{l}\mathrm{Ht} \\
\%\end{array}$ & $\begin{array}{l}\mathrm{MCH} \\
\mathrm{pg}\end{array}$ & $\begin{array}{l}\mathrm{MCV} \\
\mu^{3}\end{array}$ & $\begin{array}{c}\mathrm{MCHC} \\
\%\end{array}$ & $\begin{array}{c}\text { S.I. } \\
\mu \mathrm{g} / 100 \mathrm{~m} 1\end{array}$ & $\underset{\%}{\mathrm{Hb} \mathrm{A}} \mathrm{A}_{2}$ & $\begin{array}{c}\mathrm{Hb} F \\
\%\end{array}$ & Target cells \\
\hline \multicolumn{11}{|l|}{ Case I } \\
\hline$I-4$ & $65, F$ & 7.8 & 25 & 23.7 & 76.2 & 31.2 & 169 & 5.5 & 5.3 & + \\
\hline II -1 & $43, F$ & 12.0 & 38.5 & 23.3 & 74.7 & 31.1 & 169 & 5.2 & 3.1 & + \\
\hline II -3 & $37, \mathrm{~F}$ & 6.7 & 22.5 & 19.9 & 66.9 & 29.7 & 61 & 2.4 & 2.3 & ++ \\
\hline II -4 & $35, M$ & 11.3 & 35.5 & 21.4 & 67.2 & 31.8 & & 5.8 & .4 .1 & + \\
\hline II -5 & $31, M$ & 7.6 & 26.8 & 24.4 & 85.0 & 28.8 & & 6.0 & 4.7 & +++ \\
\hline III - 11 & $4, M$ & 12.0 & 34.5 & 20.5 & 59.1 & 34.7 & & 6.0 & 2.4 & + \\
\hline \multicolumn{11}{|l|}{ Case II } \\
\hline II -4 & $67, F$ & 11.8 & 35 & 30.3 & 89.9 & 33.7 & & 4.5 & 3.8 & + \\
\hline II -8 & $52, F$ & 7.3 & 27 & 19.6 & 72.0 & 27.0 & 290 & 5.3 & 2.5 & ++ \\
\hline III - 4 & $37, F$ & 11.9 & 38 & 30.6 & 97.9 & 31.3 & & 5.4 & 3.1 & + \\
\hline III - 9 & $27, F$ & 11.0 & 34 & 35.8 & 110.7 & 32.3 & & 5.3 & 3.0 & + \\
\hline
\end{tabular}

two apparently unrelated Japanese families with unusually severe forms of heterozygous $\beta$-thalassemia. Clinical and genetic problems are briefly discussed.

\section{CASE STUDIES}

Clinical Features.-The propositus in the first family, a thirty-one year old man, was admitted to the Kyushu University Hospital in February, 1976, because of general malaise and fever. He had been noted to be pale since childhood, and anemia was diagnosed at 9 years of age. One and half years before admission general malaise developed, and splenomegaly was noted. On physical examination, he appeared to be chronically ill, and moderately severe anemia and slight icterus were observed. The posterior portion of his skull was protruding. Brownish pigmentation was seen at both lower eyelid areas. A grade 2 systolic murmur was heard at the apical and the left sternal border areas. The liver was increased in consistency and the liver and spleen were palpable $4 \mathrm{~cm}$ and $5 \mathrm{~cm}$ below the right and left costal margins, respectively.

Urinary urobilinogen was $\#$ and bilirubin was + . Hematological data are listed in Table 1. Peripheral blood smear revealed marked anisopoikilocytosis with numerous target cells, basophilic stippling and Jolly bodies in the red cells (Fig. 1). Bone marrow examination revealed normoblastic hyperplasia, the myeloid : erythroid ratio being $1: 6$. Sideroblastic ratio was $85 \%$. Chemical analyses of the serum showed the following:

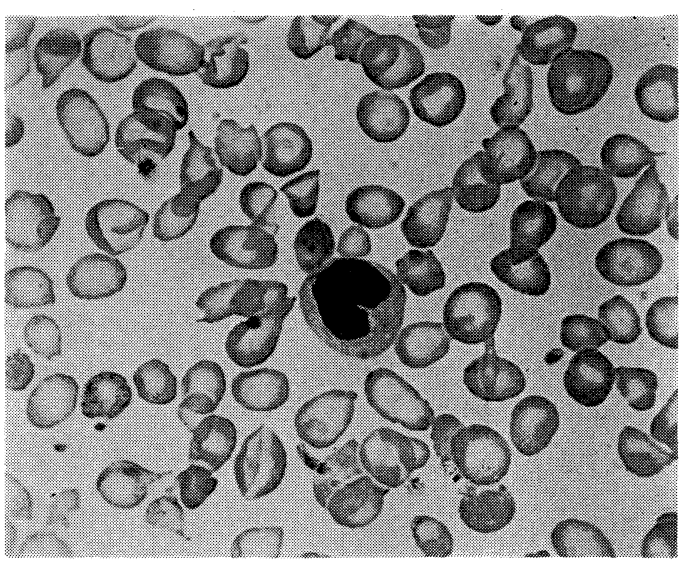

Fig. 1. Peripheral blood smear of proband (II-5), case 1. Note the marked abnormalities of red cells, including target cells, anisocytosis, poikilocytosis, Jolly bodies and basophilic stippling.

total bilirubin $2.8 \mathrm{mg}$ per $100 \mathrm{ml}(2.0 \mathrm{mg}$ indirect form); SGOT $125 \mathrm{mU}$ per ml; SGPT $74 \mathrm{mU}$ per $\mathrm{ml}$; Al-P $65 \mathrm{mU}$ per $\mathrm{ml}$; $\mathrm{LDH}$ over $600 \mathrm{mU}$ per $\mathrm{ml}$ ( I 57\%, II 29\%, III 11 $\%$, IV $1 \%, \mathrm{~V} 2 \%$ ); serum iron $247 \mu \mathrm{g}$ per $100 \mathrm{ml}$; TIBC $269 \mu \mathrm{g}$ per $100 \mathrm{ml}$. Osmotic fragility was decreased, especially after 24 hr incubation (Fig. 2). Erythrocytes enzyme activities were increased. No enzyme deficiency was noted (Table 2). Throat culture was positive for $\beta$-streptococci. X-ray films of the skull revealed thickening of the calvarium with mild "hair-brush" appearance in the parietal region (Fig. 3). Both radiographic and ultrasound examinations revealed no evidence of cholelithiasis.

Jap J Med Vol 16, No 4 (Oct 1977) 

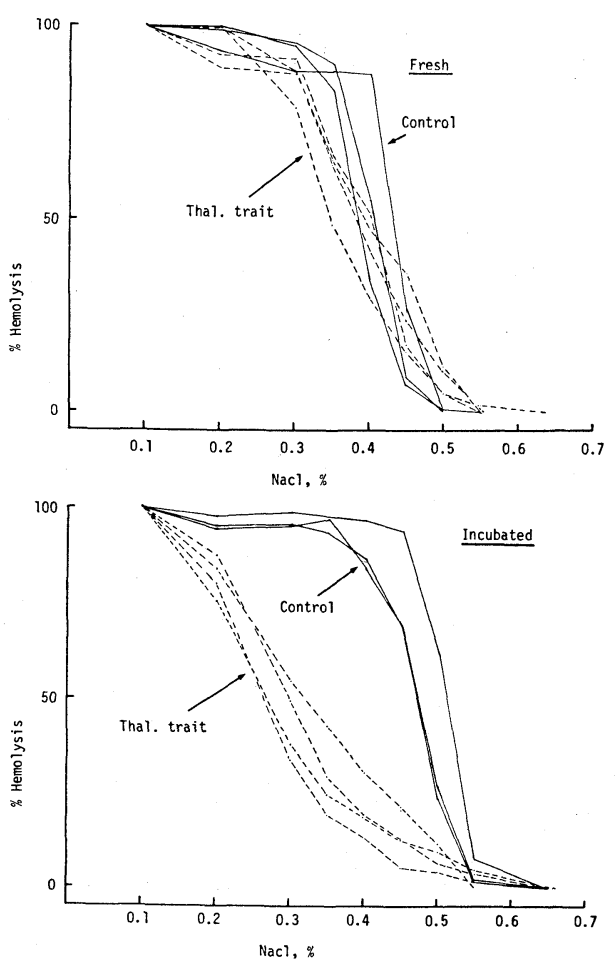

Fig. 2. Osmotic fragility was invariably decreased in all affected members, especially after $24 \mathrm{hr}$ incubation.

Table 2. Red cell enzyme activities.

\begin{tabular}{lrrr}
\hline & Normal range & Contro1 & II-5 \\
\hline Hexokinase & $0.08-0.28$ & 0.11 & 1.11 \\
Glucosephosphate isomerase & $11.2-20.0$ & 11.7 & 17.0 \\
Phosphofructokinase & $9.3-19.3$ & 14.2 & 21.4 \\
Aldolase & $0.83-3.51$ & 1.42 & 3.06 \\
Trisephosphate isomerase & $380-523$ & 605 & 919 \\
Glyceraldehyde 3-P dehydrogenase & $45.3-72.8$ & 75.1 & 142.4 \\
Phosphoglycerate kinase & $249-334$ & 297 & 438 \\
Phosphoglyceromutase & $12.2-24.2$ & 14.3 & 33.7 \\
Enolase & $2.35-7.29$ & 4.58 & 14.28 \\
Pyruvate kinase & $5.63-13.2$ & 13.18 & 38.7 \\
Lactate dehydrogenase & $108-198$ & 187 & 378 \\
Glucose 6-P dehydrogenase & $3.61-7.42$ & 4.29 & 12.73 \\
6-Phosphogluconate dehydrogenase & $5.71-10.3$ & 13.69 & 38.05 \\
Glutathione reductase & $2.96-7.15$ & 5.29 & 10.62 \\
Glutathione peroxidase & $15.5-27.9$ & 24.0 & 47.1 \\
Adenylate. kinase & $108-188$ & 138 & 186 \\
Chol inesterase* & $0.56-1.11$ & 0.71 & 0.7 \\
\hline
\end{tabular}

units/g Hb.
$\star \Delta \mathrm{pH} / 0.02 \mathrm{ml}$ RBC

Radioisotope ( $\left.{ }^{99 \mathrm{~m}} \mathrm{TC}\right)$ scanning demonstrated diffuse liver disfunction and splenomegaly. Ferrokinetic study revealed ineffective erythropoiesis (Fig. 4): plasma iron turnover $4.4 \mathrm{mg}$ per $\mathrm{kg}$ per day; iron utilization $24 \%$;

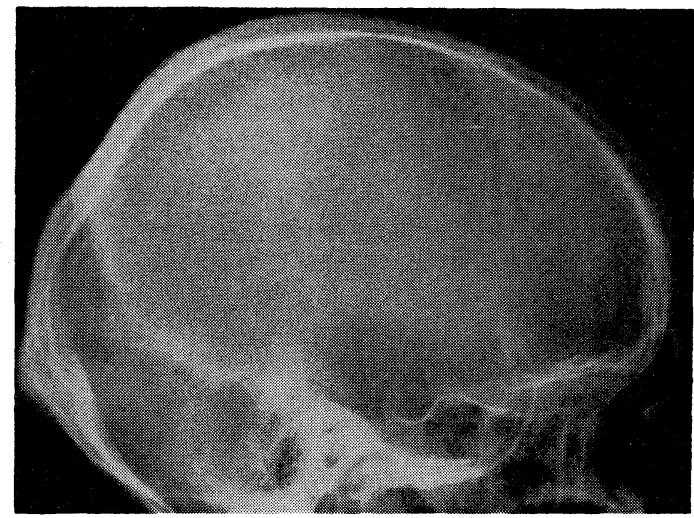

Fig. 3. Mild "hair-bruch" appearance of the skull of proband, case 1 .

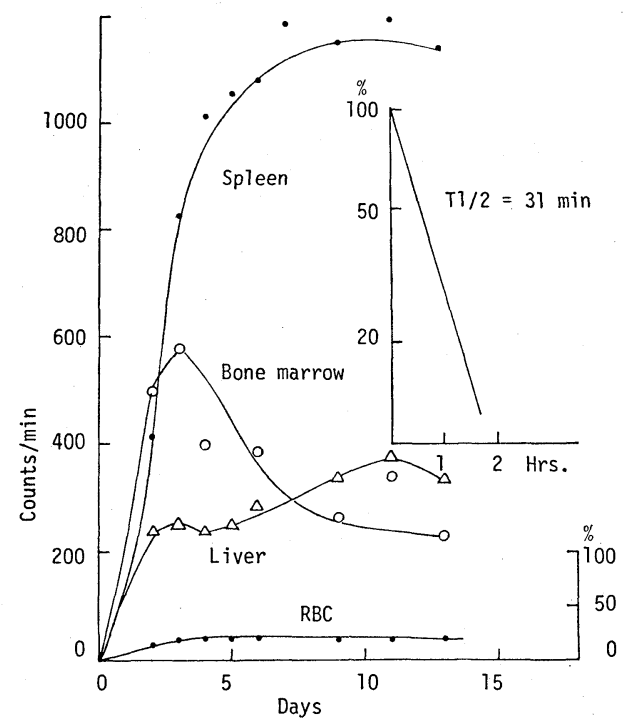

Fig. 4. Ferrokinetic profiles in a $\beta$-thalassemia intermedia heterozygote II-5 (case 1). The ${ }^{59} \mathrm{Fe}$ activity is plotted as a net count over each organ. $\mathrm{RBC}{ }^{59} \mathrm{Fe}$ incorporation is expressed as per cent of the ${ }^{59} \mathrm{Fe}$ dose injected.

and red cell iron turnover $1.07 \mathrm{mg}$ per $\mathrm{kg}$ per day. Accumulation of radioactivity over the spleen was markedly increased on surface counting while counting over the liver was not increased. ${ }^{51} \mathrm{Cr}$-red-cell survival was 13 day $(\mathrm{Tl} / 2)$. Diagnosis of chronic hemolytic anemia associated with secondary hemochromatosis was made, and $\beta$-streptococcus infection of upper respiratory tract was suspected. By maintain- 
ing bed rest and under nutritional care he was relieved of fever and general malaise. $\mathrm{His}$ hemoglobin level rose from $8 \mathrm{~g} / 100 \mathrm{ml}$ to $10 \mathrm{~g} / 100 \mathrm{ml}$ levels. However, hypochromia and microcythemia became more evident. These changes in red cell indices may have been influenced by the complication of episodic infection.

The clinical features of the second case with severe $\beta$-thalassemia have been reported $^{3)}$. Since it is relevant to include this patient with similar findings to those of case 1 , we summerize the hematological findings of the family in Table 1. The proposita is currently 55 years old, her hemoglobin level being in the range of $8-10 \mathrm{~g} /$ $100 \mathrm{ml}$. Hepatosplenomegaly, hepatolithiasis, iron overloard, abnormal erythrocyte morphology, and hemoglobin constitution have not changed much since she was examined by us for the first time. Her peripheral blood samples were recently collected to reexamine the globin synthesis ratio.

Family Study.-The family tree of the first case is shown in Fig. 5. The mother, three sibsips and a son of the propositus were found to be heterozygous for $\beta$-thalassemia. Their hematological data and hemoglobin indices are listed in Table 1. Of the 5 carriers, three members including the propositus showed severe anemia, their hemoglobin levels ranging from $6.9 \mathrm{~g} / 100 \mathrm{ml}$ to $7.8 \mathrm{~g} / 100 \mathrm{ml}$. One of these three members (II-3) had a normal $\mathrm{Hb} \mathrm{A}_{2}$ level, which appeared to be due to her iron deficiency state, while iron overload was a serious problem in other two individuals.

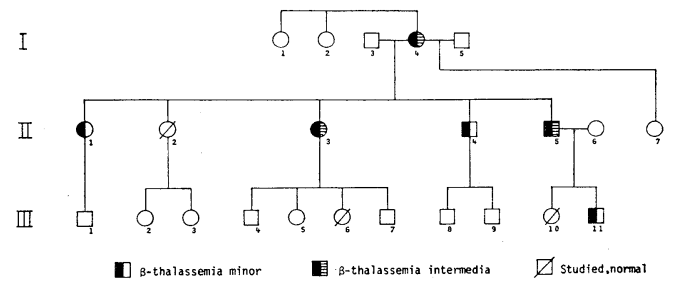

Fig. 5. Pedigree of case 1 .

\section{METHODS}

Hemoglobin was electrophoresed on thin layer starch gel as previously described ${ }^{40}$.
Hemoglobin $\mathrm{A}_{2}$ was quantitated on DEAE Sephadex chromatography according to Huisman et $\mathrm{al}^{5)}$. By this method, the normal value for hemoglobin $\mathrm{A}_{2}$ in our laboratory ranges between 2.0 and 3.5 per cent of the total hemoglobin. Alkali resistant hemoglobin was estimated by the method of Singer et $\mathrm{al}^{6}$. The thermostability test was performed either at $50^{\circ} \mathrm{C}$ for 3 hours in $0.0 \mathrm{lM}$ tris- $\mathrm{HCl}$ at $\mathrm{pH} 7.6^{7)}$, or at $37^{\circ} \mathrm{C}$ in $17 \%$ isopropanol ${ }^{8}$.

Globin chain synthesis in the peripheral reticulocytes and the bone marrow cells was studied by the method of Weatherall et $\mathrm{al}^{9)}$. Heparinized red cells obtained by venipuncture or by bone marrow aspiration were washed three times with Borsook's saline solution containing $0.13 \mathrm{M} \mathrm{NaCl}$, $0.005 \mathrm{M} \mathrm{KCl}$, and $0.0074 \mathrm{M} \mathrm{MgCl}_{2}$ and incubated with $25 \mu \mathrm{Ci}$ of ${ }^{14} \mathrm{C}$-leucine and $150 \mu \mathrm{Ci}$ of ${ }^{3} \mathrm{H}$-leucine for one hour at $37^{\circ} \mathrm{C}$, after which the red cells were washed three times with Borsook's saline, and hemolysed with $0.02 \mathrm{M} \mathrm{MgCl}_{2}$. Unlysed cells and stroma were removed by centrifugation at $12,000 \mathrm{rpm}$ for 20 minutes. Globin chains were separated by the method of Clegg et $\mathrm{al}^{10)}$. A one $\mathrm{ml}$ aliquot taken from each fraction was mixed with $10 \mathrm{ml}$ Bray's solution $^{11)}$ and radioactivity was measured with a Beckman model LS 100 liquid scintillation counter. The radioactivity was corrected for background and the total activity corresponding to the separated $\beta$ - or $\alpha$-chains was determined by integrating the radioactivity of each fraction in the peak.

In order to detect the free $\alpha$-chain pool, a fresh hemolysate $(0.5-1.0 \mathrm{ml})$ labelled with ${ }^{3} \mathrm{H}$-leucine was subjected to gel filtration of a Sephadex G-75 column $(2.0 \mathrm{~cm} \times 50 \mathrm{~cm})$ equilibrated at $4^{\circ} \mathrm{C}$ with $0.05 \mathrm{M}$ tris- $\mathrm{HCl}$ buffer containing KGN (100 mg/1), pH 7.4. The radioactivity of each fraction was counted by the method of Wood et al. ${ }^{12}$ To an aliquot $(0.2 \mathrm{ml})$ from each fraction were added $0.2 \mathrm{ml} 60 \%$ perchloric acid and $0.4 \mathrm{ml}$ $30 \%$ hydrogen peroxide. The capped vials were heated at $70^{\circ} \mathrm{C}$ for 60 minutes, followed by addition of $15 \mathrm{ml}$ scintillant by mixing toluene containing, diphenyloxazole (DPO, 
$6 \mathrm{~g} / \mathrm{l})$ with 2-ethoxyethanol in the ratio of $4: 3(\mathrm{v} / \mathrm{v})$.

\section{RESULTS}

On hemoglobin electrophoresis, no abnormal hemoglobin was detected. Hemoglobin $\mathrm{A}_{2}$ and $\mathrm{F}$ from probands and affected members were significantly increased (Fig. 6). The Betke staining showed unhomogenous distribution of hemoglobin $\mathrm{F}$ in red cells from both probands. Thermostability tests were negative and no Heinz body formation was observed. Hemoglobin synthesis data are summarized in Table 3 and Figures 7, 8, 9. Gel filtration study of peripheral blood from the proposita showed a high proportion of free $\alpha$-chain pool (Fig. $10)$.

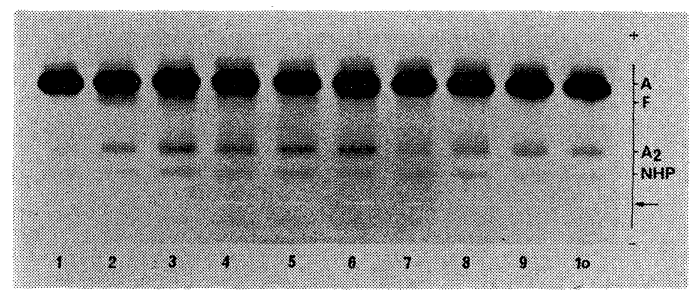

Fig. 6. Thin-layer starch gel electrophoresis (Tris-EDTA-borate buffer, $\mathrm{pH} 8.6$ ) of hemolysates from: (1) control; (2) II-5; (3) I-4; (4) II-4; (5) III-11; (6) II-1 ; (7) II-3; (8) III-6; (9) III-10; (10) II-2. Arrow indicates origin; amido black $10 \mathrm{~B}$ staining. Note increased intensity of $\mathrm{Hb} \mathrm{A}_{2}$ and $\mathrm{F}$ bands.

Table 3. Hemoglobin synthesis studies on peripheral blood and bone marrow cells.

\begin{tabular}{|c|c|c|c|c|c|c|}
\hline \multirow{2}{*}{$\begin{array}{c}\text { Subject } \\
\text { and Diagnos is }\end{array}$} & \multirow{2}{*}{\multicolumn{2}{|c|}{$\begin{array}{l}\text { Sample \& } \\
\text { Isotope }\end{array}$}} & \multirow{2}{*}{$\begin{array}{l}\text { Incubation } \\
\text { Time(min) }\end{array}$} & \multicolumn{2}{|c|}{ Total cpm } & \multirow{2}{*}{$\begin{array}{l}\text { Ratio } \\
B / \alpha\end{array}$} \\
\hline & & & & $\bar{\beta}$-chain & $\alpha-$ chain & \\
\hline \multicolumn{7}{|l|}{$\beta$-thalassemia intermedia } \\
\hline \multirow[t]{3}{*}{ Case $1,11-5$} & BM & ${ }^{14} \mathrm{C}$ & 120 & 21946 & 20726 & 1.05 \\
\hline & PB & ${ }^{14} \mathrm{c}$ & 120 & 3383 & 4684 & 0.72 \\
\hline & & ${ }^{3} \mathrm{H}$ & 60 & 33711 & 60932 & 0.55 \\
\hline \multirow[t]{2}{*}{ Case $2,11-8$} & PB & ${ }^{14} \mathrm{C}$ & 120 & 1008 & 2048 & 0.49 \\
\hline & & ${ }^{3} \mathrm{H}$ & 60 & 16606 & 36870 & 0.45 \\
\hline \multicolumn{7}{|l|}{ B-thalassemia minor } \\
\hline \multirow[t]{2}{*}{ Case $2,111-4$} & $B M$ & ${ }^{14} \mathrm{C}$ & 120 & 10926 & 10210 & 1.07 \\
\hline & PB & ${ }^{14} \mathrm{C}$ & 120 & 284 & 564 & 0.50 \\
\hline \multicolumn{7}{|l|}{ Control } \\
\hline Hereditary spherocytosis & PB & ${ }^{14} \mathrm{C}$ & 120 & 4554 & 4666 & 0.98 \\
\hline
\end{tabular}
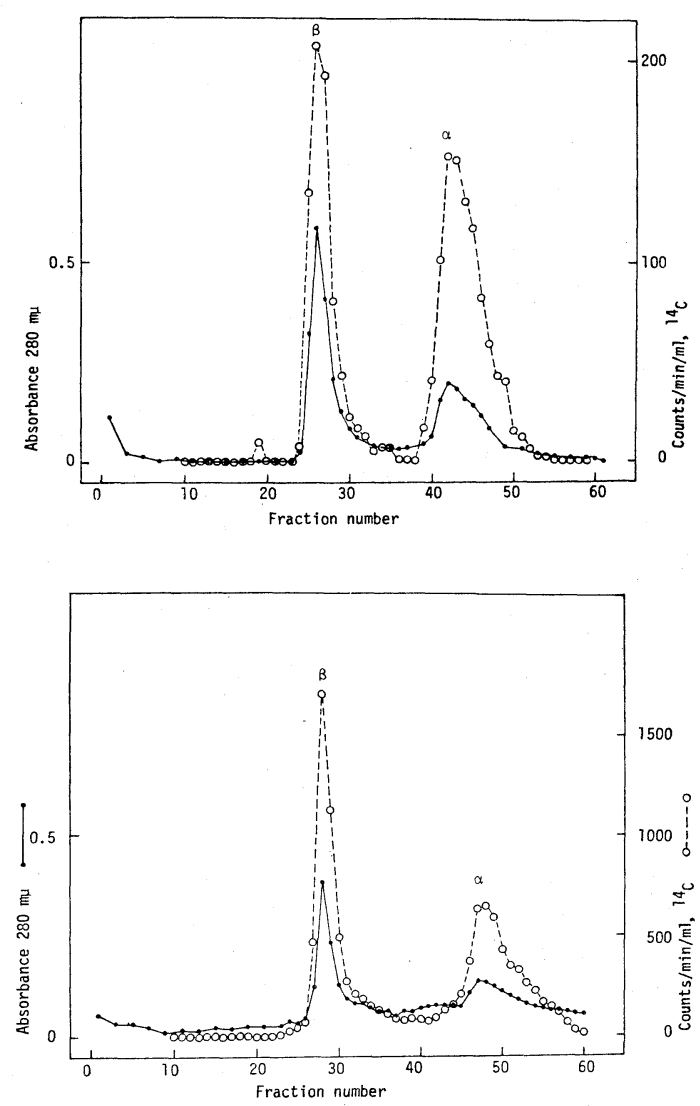

Fig. 7, 8. Hemoglobin synthesis in the peripheral blood (7) and bone marrow (8) of the propositus, case 1 .

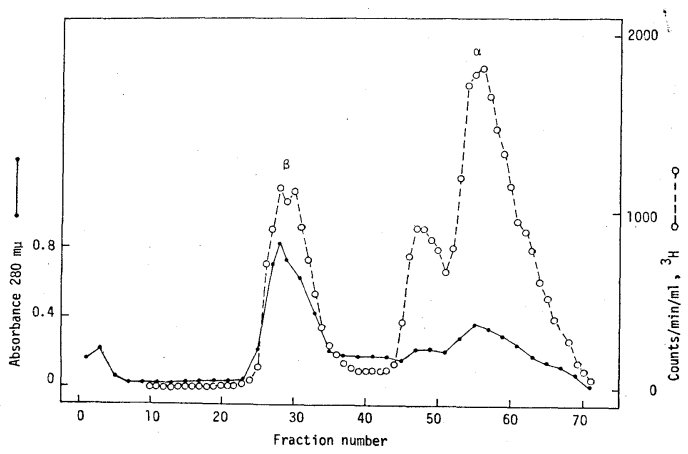

Fig. 9. Hemoglobin synthesis in the peripheral blood of the proposita, case 2 . 


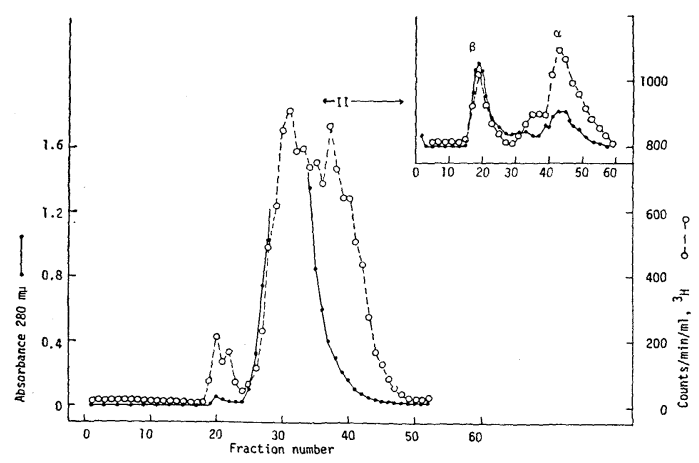

Fig. 10. Sephadex G 75 gel filtration of hemolysate prepared from proposita (case 2) after 60 minutes incubation with ${ }^{3} \mathrm{H}$-leucine; $\mathrm{O}$... $\mathrm{O}$ radioactivity, _- absorbance $280 \mathrm{~m} \mu$. The inset shows the globin pattern for fraction II with $20 \mathrm{mg}$ carrier hemoglobin. The $\beta / \alpha$ ratio was 0.25 .

\section{DISCUSSION}

The present study is concerned with $\beta$ thalassemia found in two unrelated families. Four of the 10 individuals apparently heterozygous for $\beta$-thalassemia have shown unusually severe clinical disease, while other 6 members revealed typical thalassemia minor identical in every way with those reported from other ethnic groups. In neither case was there any evidence of other racial background.

The clinical spectrum of the $\beta$-thalassemias reflects the nature of the underlying $\beta$-thalassemia mutations inherited in either heterozygous or hemozygous form, or as genetic combinations. Beta-thalassemia mutations may be of the $\beta^{+}-, \beta^{\circ}-$ and $\delta \beta-$ types in reference to whether $\beta$-chain production from the affected locus is reduced in amount or totally absent. Clinically the terms "homozygous" and "heterozygous" may be misleading. Also, it is not possible to distinguish the heterozygous state for $\beta^{+}$ and $\beta^{\circ}$-thalassemia by hematological or hemoglobin criteria $^{1)}$. Furthermore, there are milder forms of homozygous $\beta$-thalassemia lumped together as thalassemia intermedia clinically ${ }^{13,14}$. Precise genotyping may sometimes be even more difficult on clinical grounds, since few patients with heterozygous $\beta$-thalassemia, to which group some of our patients belong, have more severe clinical disease ${ }^{15-19)}$ (thalassemia intermedia) than those with typical thalassemia minor. Weatherall has reviewed these unusual cases with intermediate severity and pointed out that this apparent hetetogeneity probably represents different genetic disorders or is the result of an association with different genetic backgrounds which might modify the phenotypic expression of the $\beta$-thalassemia gene ${ }^{1)}$. At present, treatment of patients with various forms of $\beta$-thalassemia does not demand precise genotyping, but future genetic analysis may require such an awareness. In this connection, the presence of acquired disorders complicating the inherited condition should be considered and ruled out, when a patient presents with severe anemia and biochemical evidence of $\beta$-thalassemia minor ${ }^{1)}$.

Despite nearly identical biochemical results suggesting quite similar hemoglobin constitutions and $\beta / \alpha$ globin synthesis ratios, the hematologic and clinical findings of the four members in two families were distinct from the usual heterozygous $\beta$-thalassemics by showing hemoglobin concentrations in the $7-10 \mathrm{~g} / 100 \mathrm{ml}$ range, moderately severe hepatosplenomegaly, iron overload in all but one case, and hemolysis. Why apparently heterozygous $\beta$-thalassemia should occasionally be of intermediate severity is uncertain. Studies of $\beta$-chain and $\alpha$-chain production in the peripheral blood and bone marrow showed a chain imbalance similar to those seen in the usual $\beta$-thalassemia heterozygotes ${ }^{20,21)}$ : the $\beta / \alpha$ synthesis ratios of peripheral blood ranged from 0.45 to 0.72 . It is noteworthy that other members of the families showed typical $\beta$-thalassemia minor associated with only mild hypochromic anemia. We conclude that this condition represents a distinct clinical expression of $\beta$-thalassemia gene, possibly due to modification by other factors, resulting in either an increase or a decrease in the globin synthesis. There is evidence that the pool of free $\alpha$-chains in $\beta$-thalassemic cells may 
affect globin translation by decreasing $\alpha$ globin synthesis ${ }^{22}$. This mechanism is thought to provide a translational control in thalassemia as well as non-thalassemic cells. Defective or ineffective proteolytic enzyme activity, if any, in some patients' red cells, may affect the degradation of excess $\alpha$-chains present, leading to more severe damage of cells $^{12,23)}$, although this possibility is difficult to prove experimentally. That the clinical and hematologic findings were those of $\beta$-thalassemia intermedia in some patients, while the disease of other members of the family were apparently typical $\beta$-thalassemia minor, suggests that they are similar to those described for whom a "silent" $\beta$-thalassemia gene is involved ${ }^{24)}$. The $\beta / \alpha$ chain synthesis ratios in apparently normal subjects in these two families remain to be studied.

By far the most important clinical problem encountered in the $\beta$-thalassemia families is the physicians' unawareness of this disorder in the differential diagnosis of refractory anemia in Japanese people. The clinical and hematologic findings which could alert clinicians to the existence of this disorder include a mild refractory anemia, red cells showing variable hypochromia, morphological changes and basophilic stippling, a relatively high red cell count, a normal or raised serum iron level with normal or increased iron stores in the marrow, and a raised level of $\mathrm{Hb} \mathrm{A}_{2}$. Although not pathognomonic, decreased red cell ostmotic fragility, especially after 24 hours incubation at $37^{\circ} \mathrm{C}$, is useful in the differential diagnosis of this disorder from normal or other hemolytic syndromes. It must be remembered that iron deficiency can occasionally occur in $\beta$-thalassemia heterozygotes-indeed one patient in family 1 (II-3) has shown decreased serum iron level even though her blood picture was similar to those of $\beta$-thalassemia intermedia observed in her mother and brother. When $\beta$-thalassemia trait is associated with iron deficiency, $\mathrm{Hb} \mathrm{\textrm {A } _ { 2 }}$ level tends to be normal ${ }^{1}$, a fact which poses a problem in identifying the disease until administration of iron therapy is known to be effective or not in these patients. Many of the $\beta$-thalassemia heterozygotes had undergone numerous investigations, and had received repeated courses of therapy with iron and other haematinics for many years. In this connection, we must be careful since the thalassemics may have abnormal iron absorption that has been thought to be an important etiologic factor for iron overload in this disorder. Thalassemia is usually missed in Japanese patients as in other ethnic groups where its incidence is low. However, physicians must be alerted to consider this disorder in the differential diagnosis of refractory anemia to avoid unnecessary and even harmful therapy.

ACKNOWLEDGEMENTS: The authors wish to thank Dr. H.B. Hamilton of the Radiation Effect Research Foundation for his careful reading of the paper and valuable suggestions. Thanks are also due to Prof. S. Miwa of the Yamaguchi University for the erythrocytes enzyme studies, and to Drs. Y. Niho, S. Okamura, and N. Kimura for their contributions to the ferrokinetic and hematological studies.

\section{REFERENCES}

1) Weatherall DJ: The thalassemia and related disorders. Blood and Its Disorders (Hardisty RM, Weatherall DJ, eds), Blackwell Scientific Publications, Oxford, p. 630, 1974.

2) Ohta $Y$, Imamura $T$, Sumida I: Thalassemia syndromes. Jap J Clin Haematol, 15: 86, 1974. (in Japanese)

3) Sasaki J, Imamura T, Hirata H, Sumida I, Niho Y, Yamaoka K, Yanase T : Thalassemia intermedia in a Japanese family. Acta Haem Jap (in press).

4) Yamaoka K, Ohta Y, Seita M: Thin-layer starch gel electrophoresis. Jap J Clin Hamatol, $13: 800,1972$. (in Japanese)

5) Huisman THJ, Dozy AM: Studies on the heterogeneity of hemoglobin. IX. The use of tris (hydroxymethyl) aminomethane-HCl buffers in the anion exchange chromatography of hemoglobins. J Chromatogr, 19 : 160, 1965.

6) Singer K, Chernoff AI, Singer L: Studies in sickle cell anemia and other hematologic 
disorders by means of alkali denaturation. Blood, 6 : 413, 1951.

7) Dacie JV, Grimes AJ, Meisler A, Steingold L, Hemsted EH, Beaven GH, White JG: Hereditary Heinz-body anemia. A report of studies on five patients with mild anaemia. Brit J Haematol, 10 : 388, 1964.

8) Carrel RW, Kay R: A simple method for the detection of unstable hemoglobins. Brit J Haematol, 23 : 615, 1972.

y) Weatherall DJ, Clegg JB, Na-Nakorn S, Wasi P: The pattern of disordered hemoglobin synthesis in homozygous and heterozygous B-thalassemia. Brit J Haemat, 16: 251, 1969.

10) Clegg JB, Naughton MA, Weatherall DJ : Abnormal human haemoglobins. Separation and characterization of $\alpha$ - and $\beta$-chains by chromatography and the determination of variants, $\mathrm{Hb}$ Chesapeak and $\mathrm{Hb} \mathrm{J}$ (Bangkok). J Mol Biol, 19: 91, 1966.

11) Bray GA: A simple efficient liquid scintillator for counting aqueous solution in a liquid scintillation counter. Anal Biochem, $1: 297,1960$.

12) Wood WG, Stamatoyannopoulos G: Globin synthesis in fractionated normablasts of $\beta$ thalassemia heterozygotes. J Clin Invest, 55 : 567, 1975.

13) Heller P, Yakulis VJ, Rosenzweig AI, Abildgaad CF, Rucknagel DL: Mild homozygous beta-thalassemia: further evidence for the heterogeneity of beta thalassemia genes. Ann Intern Med, 64 : 52, 1966.

14) Kan YW, Nathan DG: Mild thalassemia: the result of interactions of alpha and beta thalassemia genes. J Clin Invest, 49: 635, 1970.

15) Weatherall DJ, Clegg JB, Knox-Macauley
HHM, Bunch C, Hopkins CR, Temperley IJ : A genetically determined disorder with features both of thalassemia and congenital dyserythropoietic anemia. Brit J Haematol, $24: 681,1973$.

16) MaCarthy GM, Temperley IJ, Clegg JB. Weatherall DJ: Thalassemia in an Irish family. Irish Journal of Medical Science, Seventh series, 1: 303, 1968. (quated by Weatherall DJ, in reference 1)

17) Friedman S, Ozsoylu S, Luddy R, Schwartz W: A new form of $\beta$-thalassemia trait of unusual severity. Blood, 42: 990, 1973.

18) Stamatoyannopoulos G, Woodson R, Papayannopoulou T, Heywood D, Kurachi S: Inclusion body $\beta$-thalassemia trait. A new form of $\beta$-thalassemia produsing clinical manifestations in simple heterozygotes. N Engl J Med, 939, 1974.

19) Friedman S, Ozsoylu S, Luddy R, Schwarz $\mathrm{E}$ : Heterozygous beta thalassemia of unusual severity. Brit J Haemat, 32: 65, 1976.

20) Bank A, Marks PA : Excess $\alpha$-chain synthesis relative to $\beta$-chain synthesis in thalassemia major and minor. Nature (London) 212: 1198, 1966.

21) Schwartz E: Heterozygous beta thalassemia: balanced globin synthesis in bone marrow cells. Science, $167:$ 1513, 1970.

22) Gill FM, Schwartz E: Free $\alpha$-globin pool in human bone marrow. J Clin Invest, 52 : 3057, 1973.

23) Clegg JB, Weatherall DJ : Haemoglobin synthesis during erythroid maturation in $\beta-$ thalassemia. Nature New Biol, 240 : 190, 1972.

24) Schwartz E: The silent carrier of beta thalassemia. N Engl J Med, 281: 1327, 1969. 